\title{
Antioxidant activity and total phenolic contents of dried and germinated legumes
}

Aisha Umar ( $\nabla$ ash.dr88@gmail.com )

Institute of Botany, University of the Punjab Lahore, Pakistan

Muhammad Tajammal Khan

Department of Botany Division of Science and Technology University of Education Lahore, Pakistan

Shanila Bukhari

Institute of Botany, University of the Punjab Lahore, Pakistan

Rehana Sardar

Institute of Botany, University of the Punjab Lahore, Pakistan

Kishwar Naheed

Institute of Botany, University of the Punjab Lahore, Pakistan

Hajira Younas

Institute of Botany, University of the Punjab Lahore, Pakistan

\section{Saber Hussain}

Institute of Botany, University of the Punjab Lahore, Pakistan

Raazia Alam Gillani

Institute of Botany, University of the Punjab Lahore, Pakistan

Rushaan Kauser Kiani

Institute of Botany, University of the Punjab Lahore, Pakistan

\section{Research Article}

Keywords: beans, diseases, spectrophotometer, radicles, scavenging activity

Posted Date: February 10th, 2022

DOI: https://doi.org/10.21203/rs.3.rs-1239490/v1

License: (c) (i) This work is licensed under a Creative Commons Attribution 4.0 International License. Read Full License 


\section{Abstract}

Beans and lentils are good sources of total phenolic contents and possessed excellent free radical scavenging activity. This study was aimed to assess the total phenolic compounds (TPCs) and antioxidant activity of dried and germinated beans and lentils. The total phenolics contents were extracted from seven types of beans and lentils by using $50 \%$ (v/v) aqueous ethanol. The TPCs and antioxidant activities were analyzed using Folin-Ciocalteu and DPPH (2, 2-diphenyle-1picrylhydrazyl radical), ABTS (2,2'-azinobis-(3-ethylbenzothiazoline-6-sulphonate) assays, respectively. The legumes showed the highest total phenolic contents (TPCs) and antioxidant capacity by DPPH and ABTS scavenging activity ( $p<$ 0.05 ) in germinated samples. The germinated beans and lentils contained more total phenolic contents that decrease significantly in dried beans. This study also suggested that germinated beans are a valuable source of commercial natural antioxidants.

\section{Introduction}

Legumes are cultivated and an essential part of human meals throughout the world ${ }^{1}$. The consumption of phenolic rich legumes is maximum in Asia than other continents due to therapeutic effects of numerous bioactive compounds that influence the human metabolic machinery ${ }^{2}$. The legumes also contain protein and minerals with low glycemic index) and also maintain the bone health ${ }^{3}$.

Legumes contain many antioxidant compounds like anthocyanins, procyanidins, tannins, flavonoids (flavanols) and phenolic (Flavan-3-ols) derivatives ${ }^{4}$, which combat with cardiovascular diseases ${ }^{5}$, breast cancer and provide protection against hypercholesterolemic effects.

The polyphenols of legumes play a vital role in metabolic and physiological processes ${ }^{6}$, which hinder the production of free radicals formed by the breakage of biological molecules (lipids, protein, DNA) in our body ${ }^{7}$. The water insoluble polyphenols act as anti-artherogenic, anti-inflammatory, antimutagenic and antimicrobial activities ${ }^{8}$.

Germination stage of legumes causes change in biological activities due to these compounds during respiration and new cell formation. This is an efficient stage to enhance the nutrient activities (amino acid, dietary fibers, and soluble sugar) and various other compounds of legume and pulses ${ }^{9}$.

The aim of this study was to explore the total phenolic compounds (TPCs) and antioxidant activity of dried and germinated beans and lentils.

\section{Materials And Methods}

\section{Sample preparation}

Five types of beans including white chickpeas (Cicer arietinum), black chickpeas (Cicer arietinum), red beans (Phaseolus vulgaris), cowpea (Vigna unguiculata), mung beans (Vigna radiata) and two types of lentils masoor (Lens culinaris) and white lentils (Vigna mungo) were selected for analysis and purchased randomly from Gulberg, Lahore, Pakistan in 2019. Each sample was divided into six equal portions. Three portions of each sample were analysed for antioxidant activity of total phenolic contents, while the other three were subjected to germination.

\section{Germination of samples and measurement}

An aliquot of 2-3 g of each bean/lentil sample was cleaned with running water, and then soaked in water for $1 \mathrm{~h}$ at $28^{\circ} \mathrm{C}$. After removing excess water, seeds were placed into a sprouter $(60 \times 150 \mathrm{~mm})$ and kept in the dark at $28^{\circ} \mathrm{C}$ for germination. The sprouts germination with radicle period was $120 \mathrm{~h}$. The seeds were moistened with water after every 24 
h. Incubate at $28{ }^{\circ} \mathrm{C}$ till $90 \%$ beans were germinated. Elongation of the germinated bean/lentils radicles were taken by measuring scale $(\mathrm{cm})$. Percentage Elongation of radicles were determined by $\% E L=L_{f} L_{o} / L_{o} \times 100$.

\section{Extraction of samples}

Each sample (2-3 g) was grinded and extracted in a capped centrifuge tube with $50 \mathrm{~mL}$ solvent of ethanol/water (50\% $\mathrm{v} / \mathrm{v})$. At temperature $\left(25^{\circ} \mathrm{C}\right)$, the mixture was well shaken $(300 \mathrm{rpm})$ for $3 \mathrm{~h}$. After centrifugation, the mixture was placed under darkness for 12-24 h. Supernatant was taken from extracts into a new tube after centrifugation at $4000 \mathrm{rpm}$ for 10 min. Residues left behind in the tube were also extracted with $10 \mathrm{~mL}$ of respective solvent. Both extracts were combined and stored at $4{ }^{\circ} \mathrm{C}$ in the dark until further analysis.

\section{Preparation of analysis solutions}

(A) Gallic acid standard solution. Gallic acid stock solution was prepared by mixing $0.100 \mathrm{~g}$ gallic acid in $100 \mathrm{~mL}$ distilled water. Series of working standards of gallic acid were prepared by taking 10, 20, 50, 100, 150 and $200 \mu$ l of stock solution for total $5 \mathrm{~mL}$ constituents to prepare a standard curve in the linearity range of $2 \mu \mathrm{g}-40 \mu \mathrm{g} \mathrm{mL}{ }^{-1}$. (B) DPPH (2, 2-diphenyle1-picrylhydrazyl radical) solution $(0.1 \mathrm{mM})$. To prepare $0.1 \mathrm{mM}$ of DPPH solution, $39.4 \mathrm{mg}$ of DPPH was accurately weighed and dissolved in $1 \mathrm{~L}$ of ethanol. (C) ABTS (2,2'-Azinobis-(3-Ethylbenzothiazoline-6-Sulphonate) solution (0.1 mM). To prepare $0.1 \mathrm{mM}$ of DPPH solution $0.22 \mathrm{mg}$ of ABTS was accurately weighed and dissolved in $1 \mathrm{~L}$ of ethanol.

\section{Determination of TPCs}

Folin-Ciocalteu reagent was used to determine the total phenolic contents accordingly Xu and Chang ${ }^{10}$. Extract (50 $\mu$ l) was homogenized with $250 \mu \mathrm{l}$ of Folin-Ciocalteu reagent, $750 \mu \mathrm{l}$ of $7 \% \mathrm{Na}_{2} \mathrm{CO}_{3}(\mathrm{~W} / \mathrm{V})$ and $3 \mathrm{~mL}$ of distilled water and left for 8 min. Add $950 \mu \mathrm{l}$ of distilled water again and allow to settle for $2 \mathrm{~h}$ in room T. Absorbance $(765 \mathrm{~nm})$ was measured by using distilled water as a blank in UV/Visible spectrophotometer (Schimadzu UV 1700). All determinations were done in triplicate $(n=3)$. The quantity of total phenolic contents was determined from the standard curve of gallic acid and stated as gallic acid equivalent ( $\mathrm{mg} \mathrm{GAE} / \mathrm{g}$ ) of beans and lentils. The linearity range of the calibration curve of Gallic acid was 2 $\mu \mathrm{g}-40 \mu \mathrm{g} \mathrm{mL} \mathrm{L}^{-1}$ and $r^{2}=0.9991$ (Figure 1).

\section{Determination of antioxidant capacity (AC)}

(A) $D P P H\left(2,2-d i p h e n y l e-1-p i c r y l h y d r a z y l\right.$ radical). The method modified by $\mathrm{Xu}$ and $\mathrm{Chang}^{10}$ was used to determine antioxidant activity. Ethanolic DPPH solution of $3.8 \mathrm{~mL}(0.1 \mathrm{mM})$ was mixed in $0.2 \mathrm{~mL}$ of legume extract. Vortexing this mixture for $1 \mathrm{~min}$ and then placed in darkness (30 min). Absorbance was measured at $517 \mathrm{~nm}$ of the resulting solution $\left(A_{\text {sample }}\right)$ by a spectrophotometer (Schimadzu UV 1700) using ethanol as a blank. For the control set, respective extraction $(0.2 \mathrm{~mL})$ was added into $3.8 \mathrm{~mL}$ of DPPH solution and absorption $\left(\mathrm{A}_{\text {control }}\right)$ was measured at $517 \mathrm{~nm}$. The DPPH discoloration of the sample was calculated in percent according to the equation $=\left[1-\left(A_{\text {sample }} / A_{\text {cont }}\right)\right] \times 100$. The antioxidant content was determined using $\mathrm{BHA}$ as an external standard. A calibration curve of BHA was used to calculate the AOs with a unit of micrograms of BHA equivalents per $100 \mathrm{~g}$ of dried beans or germinated bean with sprouts $(\mu \mathrm{g}$ $\mathrm{BHA} / 100 \mathrm{~g})$ under the same experimental conditions. (B) ABTS (2,2'-azinobis-(3-ethylbenzothiazoline-6-sulphonate). Add $3.0 \mathrm{~mL}$ of diluted ABTS $(0.1 \mathrm{mM})$ solution $(A 734 \mathrm{~nm})$ to $0.2 \mathrm{~mL}$ of the legumes extracts, the absorbance was taken exactly 10 min after the initial mixing. The ABTS scavenging activity of each seed extract was calculated as a difference between the initial absorbance and that after reacting for $10 \mathrm{~min}$. Methanol was used as the blank solution. All determinations were performed in triplicate. The antioxidant content was determined using BHA as an external standard. A calibration curve of $\mathrm{BHA}$ was used to calculate the AOs with a unit of micro grams of BHA equivalents per $100 \mathrm{~g}$ of dried beans or germinated bean with sprouts ( $\mu \mathrm{g} B \mathrm{HA} / 100 \mathrm{~g})$ under the same experimental conditions.

\section{Statistical analysis}


Results were expressed as mean \pm standard deviation. Data were statistically analysed using software SPSS. Significance difference in total phenolic contents and antioxidant activities between germinated and non-germinated beans and lentils was determined at $p<0.05$ by applying ANOVA of means. The $p<0.05$ was considered statistically significant.

\section{Results}

\section{Effects of germination time on radicles elongation}

Elongation of the germinated bean/lentils radicles exhibited a quick tendency during the germination period of $120 \mathrm{~h}$. The elongation of radicles during germination time of $120 \mathrm{~h}$ in cowpea, red beans and lentils masoor was 23.3, 21.5 and 14.5 $\mathrm{cm}$ than other beans/lentils. The elongation percentage of radicles during germination time of $72 \mathrm{~h}$ was decreased in Phaseolus vulgaris, Lens culinaris, and Vigna unguiculata than other beans and lentils. It suggested that the elongation efficacy of radicles were decreased with the extension of germination time. Hence, the most effective elongation period of radicles was the early $1-3$ days of germination (Figure 2 ).

The percentage (\%) elongation of radicles in the germinated beans/lentils were $87.32 \%, 77.33 \%$, and $72.59 \%$ in Lens culinaris, Phaseolus vulgaris, and Vigna radiata sprouts, respectively in a time-dependent manner and reached the peak on $72 \mathrm{~h}$, but the values reduced in percentage elongation from $87.32-56 \%$ and $25 \%$ on day 4 and 5 respectively in Lens culinaris. The elongation percentage of radicles was $48-77.33 \%$ and $36 \%$ in Phaseolus vulgaris and $41-72.59 \%$ and $28 \%$ in Vigna radiata on day 4 and 5, respectively. The least percentage was observed in Vigna mungo (25.86\%) on day 5 (Figure 3).

\section{Quantity of total phenolic in dried and germinated seeds}

The result of our study indicated that TPCs in all beans and lentils have been significantly increased $(p<0.05)$ after germination (Table 1).

Table 1

Comparison in Percentage Increase in Total Phenolic Contents of Dried and Germinated Legumes

\begin{tabular}{|llll|}
\hline \multicolumn{4}{|l}{ Total phenolic contents (mg of GAE/g) } \\
Common name & scientific name & Germinated beans/lentils & Dried beans/lentils \\
\hline Red beans & Phaseolus vulgaris & $15.4 \pm 0.01 \mathrm{a}$ & $3.49 \pm 0.41 \mathrm{~b}$ \\
\hline Masoor (lentils) & Lens culinaris & $11.8 \pm 0.16 \mathrm{~b}$ & $1.49 \pm 0.03 \mathrm{~d}$ \\
\hline Mung & Vigna radiata & $10.2 \pm 0.08 \mathrm{c}$ & $2.79 \pm 0.33 \mathrm{c}$ \\
\hline Mash (White lentils) & Vigna mungo & $8.93 \pm 0.05 \mathrm{~b}$ & $6.62 \pm 0.55 \mathrm{a}$ \\
\hline Cowpea & Vigna unguiculata & $3.5 \pm 0.14 \mathrm{~d}$ & $2.34 \pm 0.07 \mathrm{c}$ \\
\hline Black chick peas & Cicer arietinum & $2.8 \pm 0.06 \mathrm{e}$ & $1.70 \pm 0.23 \mathrm{~d}$ \\
\hline White chick peas & Cicer arietinum & $2.5 \pm 0.01 \mathrm{~d}$ & $1.83 \pm 0.55 \mathrm{c}$ \\
\hline
\end{tabular}

Literature cited that legume fractions and germination time were affected $(p<0.05)$ on TPC. Total phenolic contents were significantly $(p<0.05)$ increased in a time-dependent manner after the germination than the original concentration of leguminous seeds. In this study, the germinated sample of red beans (Phaseolus vulgaris) exhibited the maximum amount of TPCs (15.40 mg GAE/g), which was low in white chickpeas (Cicer arietinum) (2.52 mg of GAE/g).

In white lentils of this work, TPCs value was $8.93 \mathrm{mg} \mathrm{GAE} / \mathrm{g}$ ) and $6.62 \mathrm{mg} \mathrm{GAE} / \mathrm{g}$ in germinated and dried seeds, respectively. The TPCs of Lens culinaris $(1.49 \mathrm{mg} \mathrm{GAE} / \mathrm{g}$ ) were lower amongst the remaining samples of this study (Table 
1).

In this research work, the TPCs of germinated legumes were observed in the following order: Red beans (Phaseolus vulgaris) $15.40>$ Masoor (Lensculinaris) $11.76>$ Mung (Vigna radiata) $10.2>$ Mash (Vigna mungo) $8.93>$ Cowpea (Vigna unguiculata) $3.46>$ Black chickpae (Cicer arietinum) $2.79>$ White chickpeas (Cicer arietinum) $2.52 \mathrm{mg} \mathrm{GAE} / \mathrm{g}$. The decreasing order of dried legumes were following: Mash (Vigna mungo) $6.62>$ Red beans (Phaseolus vulgaris) $3.49>$ Mung (Vignaradiata) $2.79>$ Cowpea (Vigna unguiculata) $2.34>$ White chickpea (Cicer arietinum) $1.83>$ Black chickpeas (Cicer arietinum) $1.70>$ Masoor (Lensculinaris) $1.49 \mathrm{mg} \mathrm{GAE} / \mathrm{g}$ (Table 1).

The low-molecular-weight antioxidants like phenolic compounds particularly provide the antioxidant capacity to the lentils. Germination time and legume fractions were also influenced on antioxidant capacity. The extracts of germinated and dried legumes exhibited different antioxidant capacity, and the values ranged from 0.74 to $14.01 \mu \mathrm{g}$ equivalent of $\mathrm{BHA} / 100 \mathrm{~g}$ and 4.63 to $14.06 \mathrm{\mu g}$ equivalent of $\mathrm{BHA} / 100 \mathrm{~g}$ respectively in the case of DPPH with statistically significant differences. The germinated red beans extract has the highest total antioxidant capacity in DPPH $(18.59 \mu \mathrm{g} / 100 \mathrm{~g})$ than dried beans $(14.06 \mu \mathrm{g} / 100 \mathrm{~g})$. Similarly, dried white beans (Cowpea) were lowest $(0.74 \mu \mathrm{g} / 100 \mathrm{~g})$ than germinated seeds $(3.76 \mu \mathrm{g} / 100 \mathrm{~g})$. Germinated beans/lentils exhibited better radicle scavenging activity with ABTS rather than DPPH in Mash (White lentils), Cowpea, Black chickpeas and White chickpeas of this study. The ABTS is also better than DPPH in determination of phenolic contents in dried seeds and lentils as well. In this study, germinated lentils (Masoor) contained maximum ACs $(14.01 \mu \mathrm{g} / 100 \mathrm{~g})$ than dried lentils (Masoor) (Table 2)

Table 2

Antioxidant Activity and DPPH•Radical Scavenging Activity of Dried and Germinated Legumes.

\begin{tabular}{|c|c|c|c|c|c|c|c|}
\hline & & $\begin{array}{l}\% \\
\text { inhibition } \\
\text { of } 0.1 \mathrm{mM}\end{array}$ & $\begin{array}{l}\% \\
\text { inhibition } \\
\text { of } 0.1 \mathrm{mM}\end{array}$ & $\begin{array}{l}\text { Antioxidant a } \\
\text { ( } \mu \text { g equivalen }\end{array}$ & $\begin{array}{l}\text { ivity } \\
\text { of BHA } 100 \mathrm{~g} \text { ) }\end{array}$ & & \\
\hline $\begin{array}{l}\text { Common } \\
\text { name }\end{array}$ & $\begin{array}{l}\text { Scientific } \\
\text { name }\end{array}$ & $\begin{array}{l}\text { ABTS } \\
\text { (GB/L) }\end{array}$ & $\begin{array}{l}\text { DPPH } \\
\text { (GB/L) }\end{array}$ & GB/L(DPPH) & DB/L(DPPH) & GB/L(ABTS) & $\mathrm{DB} / \mathrm{L}(\mathrm{ABTS})$ \\
\hline $\begin{array}{l}\text { Red } \\
\text { beans }\end{array}$ & $\begin{array}{l}\text { Phaseolus } \\
\text { vulgaris }\end{array}$ & $82.78 \pm 0.07$ & $67.49 \pm 3.43$ & $18.59 \pm 0.01 a$ & $14.06 \pm 2.87 a$ & $15.01 \pm 0.87 b$ & $12.06 \pm 1.7 a$ \\
\hline $\begin{array}{l}\text { Masoor } \\
\text { (lentils) }\end{array}$ & $\begin{array}{l}\text { Lens } \\
\text { culinaris }\end{array}$ & $67.31+0.02$ & $4.70 \pm 0.30$ & $14.01 \pm 0.02 b$ & $4.52 \pm 0.81 \mathrm{c}$ & $13.06 \pm 2.7 c$ & $8.06 \pm 1.87 c$ \\
\hline Mung & $\begin{array}{l}\text { Vigna } \\
\text { radiata }\end{array}$ & $57.86+0.10$ & $16.20 \pm 0.55$ & $11.21 \pm 0.01 \mathrm{c}$ & $1.12 \pm 0.94 \mathrm{e}$ & $11.09 \pm 2.17 d$ & $10.26 \pm 1.2 b$ \\
\hline $\begin{array}{l}\text { Mash } \\
\text { (White } \\
\text { lentils) }\end{array}$ & $\begin{array}{l}\text { Vigna } \\
\text { mungo }\end{array}$ & $50.97+0.08$ & $35.63 \pm 1.62$ & $9.17 \pm 0.01 d$ & $4.63 \pm 1.97 b$ & $14.6 \pm 2.5 \mathrm{~b}$ & $11.6 \pm 3.7 a$ \\
\hline Cowpea & $\begin{array}{l}\text { Vigna } \\
\text { unguiculata }\end{array}$ & $22.50+0.06$ & $7.28 \pm 2.42$ & $3.76 \pm 0.02 c$ & $0.74 \pm 3.05 d$ & $13.87 \pm 1.07 \mathrm{c}$ & $09.8 \pm 1.8 b$ \\
\hline $\begin{array}{l}\text { Black } \\
\text { chick } \\
\text { peas }\end{array}$ & $\begin{array}{l}\text { Cicer } \\
\text { arietinum }\end{array}$ & $15.18+0.05$ & $5.90 \pm 1.53$ & $1.42 \pm 0.04 d$ & $4.17 \pm 2.05 \mathrm{c}$ & $21.5 \pm 2.2 a$ & $8.06 \pm 3.0 \mathrm{c}$ \\
\hline $\begin{array}{l}\text { White } \\
\text { chick } \\
\text { peas }\end{array}$ & $\begin{array}{l}\text { Cicer } \\
\text { arietinum }\end{array}$ & $12.13+0.06$ & $3.27 \pm 0.53$ & $2.32 \pm 0.01 \mathrm{e}$ & $4.95 \pm 0.96 c$ & $14.06 \pm 1.7 c$ & $10.02 \pm 2.7 a$ \\
\hline
\end{tabular}

Estimation of radical scavenging activity. $\mathrm{DPPH}^{\cdot+}$ and $\mathrm{ABTS}^{\circ+}$ are a stable, simple and quick organic radical used to estimate the antioxidant capacity useful to evaluate the free radical scavenger activity in legumes. The antioxidant action 
of beans is interlinked with the quantity of polyphenols. The antioxidant capacities significantly differ amongst the samples of this work. The observed DPPH and ABTS scavenging capacity of the ethanol-based extracts of beans and lentils were given, which significantly higher in germinated red beans (Table 2). The scavenging activity in percentage inhibition (ABTS) of germinated beans and lentils extract decreased in the following order: Phaseolus vulgaris $>$ Lens culinaris $>$ Vigna radiata $>$ Vigna mungo $>$ Vigna unguiculata $>$ Cicer arietinum (black) > Cicer arietinum (white). Whereas in DPPH the order of inhibition in germinated beans/lentils was Phaseolus vulgaris > Vigna mungo > Vigna radiata > Vigna unguiculata > Cicer arietinum (black) > Lens culinaris > Cicer arietinum (white) (Table 2).

Significant positive correlation was observed between phenolics and antioxidant activity by DPPH and ABTS scavenging activity in the various legume extracts. The data revealed that germinated beans possessed highest total phenolic contents with antioxidant activity than lentils. The free radical scavenging activity of beans and lentils increased in both germinated beans and lentils along total phenolic contents. It means total phenolic contents are the major contributor in analysis of antioxidant capacity of beans and lentils. In this study, red beans (Phaseolus vulgaris) were stronger free radical scavengers, because of high level of total phenolic contents and antioxidant capacity.

\section{Conclusion}

The cultivars of beans and lentils processed different amount of total phenolic contents as well as antioxidant activity. The germinated beans and lentils contained more phenolic contents that decrease significantly in dried beans. The germinated beans were valuable source of natural antioxidants and sprouting was the best stage to increase few nutritional ingredients and antioxidants in beans and lentils.

\section{Discussion}

Elongation efficacy of radicles was effective in first three days ${ }^{11}$, similarly to results of this study, contrary to 3 to 4 -daygermination in work of Zhou and Zhang ${ }^{12}$. Legumes are famous for total phenolic compounds rather than rice, corn, millet and wheat. Major classes of phenolic contents in beans and lentils have been gaining popularity due to antioxidant activity. The levels of natural endogenous antioxidants (e.g., phenolics, tocopherols; vitamin $\mathrm{C}$ ) vary during seed germination of legumes. Federica et al. ${ }^{6}$ analysed 14 polyphenolic compounds ranging from $3 \mathrm{mg} \mathrm{kg}^{-1}$ for dehulled red lentils to $1630.5 \mathrm{mg} \mathrm{kg}^{-1}$ for ruviotto beans.

Legume fractions and germination time were affected on TPC. The total phenolic contents were increased after the germination. Similarly, the TPC contents were significantly $(p<0.05)$ increased with the germination time in seed hulls, radicles, cotyledons of legume ${ }^{13}$ and lentil seeds. Contrary results were shown by lentils and beans of Aguilera et al. ${ }^{14}$ and Duenas et al. ${ }^{15}$. No change in TPCs was shown by kidney beans, but the values were highly decreased in lentils ${ }^{16}$. Our results regarding TPCs were significantly higher than common bean seed coats (0.69-3.32 mg GAE/g) reported by ChávezMendoza et al. ${ }^{13}$.

The high amount of polyphenols were also found in black, brown, red beans ${ }^{17}$, adzuki bean ${ }^{18}$, and faba bean (40.7 to 66.1 $\left.\mathrm{mg} \mathrm{g}^{-1}\right)^{19}$ extract, whereas low in pea ${ }^{20}$, broad beans ${ }^{21}$, lupins ${ }^{22}$, white beans ${ }^{23}$ and grass pea ${ }^{24}$. The dried beans of our black (1.70 mg GAE/g) and white chickpeas (1.83 mg GAE/g) possessed the lowest value of TPCs compared to Fenugreek (5.79 mg gallic acid/g), (56.14 mg gallic acid/g) and chickpea seeds (5.68 mg gallic acid/g), (57.94 mg gallic acid/g) 25 .

The TPCs of Lens culinaris (1.49 mg GAE/g) were lower amongst the remaining samples of this study (Table 1), similarly in lentils of Salem et al. ${ }^{26}$ (60.39 mg GAE/g), Nair et al. ${ }^{27}\left(1191 \mathrm{mg} . \mathrm{kg}^{-1}\right)$ and Awada et al. ${ }^{28}\left(4730 \mathrm{mg} . \mathrm{kg}^{-1}\right)$, whereas Amarowicz et al. ${ }^{7}$ and Zhao et al. ${ }^{29}$ demonstrated the highest phenolic content $\left(47.6 \mathrm{mgg}^{-1}\right)$ in lentils than beans. Contrarily, maximum values were reported in red and green lentils $\mathbf{s}^{7,30}$. 
There are two schools of thought behind low level of TPCs during germination: 1) sprouting causes the reduction in flavan-3-ols and anthocyanin ${ }^{15} ; 2$ ) reactive oxygen species (ROS) released from metabolically active cells of seed, which influenced the biological process of seed germination. ROS as a messenger transmits environmental signals during seed germination and responsible for lowering the antioxidant activity of bean and lentils after germination ${ }^{31}$. TPCs were decreased in peanuts, soybeans and lentils after germination ${ }^{32}$ contrary to this study (Table 1), while Khang et al. ${ }^{33}$ values were significantly increased during germination in all legumes. Zhaohui et al. ${ }^{34}$ investigated TPCs and antioxidant activity of germinated Mung beans, soybeans and black beans sprouts were highest initially (44.87-90.31\%) then decreased.

In white lentils of this work, the TPCs were comparable to faba beans $(7.11 \mathrm{mg} \text { gallic acid/g) })^{35}$ and lupine seeds (8.56 mg gallic acid $/ \mathrm{g})^{36}$. Emily et al. ${ }^{37}$ worked on 14 Canadian pulses included beans, peas, lentils and analyzed antioxidant activity (1.16 to $7.45 \mathrm{mg} \mathrm{GAE} / \mathrm{g} \mathrm{DW}$ ) and revealed that samples with dark testa (black lentils and diavoli beans) possessed higher antioxidant activity than pale testa.

Antioxidant capacity (AC) of legumes is due to active micro and macro elements (polysaccharides, vitamins, amino acids proteins) ${ }^{38}$. In this study, germinated lentils (Masoor) contained maximum ACs than dried lentils (Masoor) similarly the work of Dalaram et al. ${ }^{39}$ but contrary to lentils of Gubanenko et al. ${ }^{40}$ and Zhao et al. ${ }^{29}$. Researchers supported that AOA (Antioxidant activity) increased as the germination time increased ${ }^{25}$, e.g., in mung beans, soybeans, black beans ${ }^{33}$, lentil seeds ${ }^{41}$, kidney beans ${ }^{14,16}$, chickpea seeds, fenugreek seeds, lentil seeds ${ }^{26}$ and lupine seeds ${ }^{36}$. Though, black beans did not change AOA during the germination process ${ }^{42}$.

Gubanenko et al. ${ }^{40}$ revealed that seedlings of lentils show a slightly higher antioxidant activity than chickpea sprouts, whereas seeds of green pea, chickpea ${ }^{43}$ and faba beans ${ }^{39}$ dramatically contained maximum TAC. The seed coat of common bean exhibited greater antioxidant capacity $(23.86-84.10 \%)$ than the cotyledon $(0.66-29.77 \%)$ of all bean varieties $^{13}$.

The most famous legumes with maximum antioxidant compounds in dietary fibres were found in chickpeas (Cicer arietinum), pulses ${ }^{44}$, white and red beans (Phaseolus vulgaris), which promote the health and prevent chronic diseases ${ }^{45}$. The result of this study regarding scavenging activity was similar to Saleh et al. ${ }^{25}$. They explained common beans $(84.52 \%)$ contained highest radical scavenging activity than lupine seeds (78.29\%). The values of lentils scavenging capacity of this study were significantly higher than $38.5 \%{ }^{29}$.

The antioxidant activity of beans increased after germination and decreased in lentils depends upon type and conditions of germination ${ }^{46}$, similarly to this study, where free radical scavenging activity increased in germinated seeds depend on the time taken for germination. Wang et al. ${ }^{47}$ worked on Chinese beans, spring bay beans, black beans, pearl beans and determined the strong positive relationship between total phenolic contents and antioxidant activities. Black, red, green beans, red kidney beans and soybeans possessed higher total phenolic contents and antioxidant capacity, whereas red and yellow lentils (dhal) and chickpea possessed lower capacity 48 .

\section{Conclusion}

This study concluded that germinate legumes exhibited the highest total phenolic contents (TPCs) and antioxidant capacity which decreased significantly in dried samples. This study also suggested that germinated beans are a valuable source of commercial natural antioxidants.

\section{Declarations}

\section{Conflict of interest}


Authors declare no conflict of interest.

Authors' contribution statement

All the authors mentioned in this study contributed equally in this work.

\section{Funding}

N/A

\section{Ethical Approval}

Not applicable

\section{Consent to Participate}

Not applicable

Consent to Publish

Not applicable

\section{Authors Contributions}

Aisha Umar contributed to complete this work in all aspects.

\section{Competing interests}

There is no any conflict of interest.

\section{Ethics approval}

I want to opt traditional publishing model for publishing my this work.

\section{Consent for publication}

I allow the journal to publish my work.

Code availability

N/A

Declaration of deposition in repositories

N/A

Experiments on live vertebrates and/or higher invertebrates/human subjects

N/A

\section{Permission to use Plant material}

N/A 
Data availability" / "Availability of Data and Materials"

N/A

\section{Datasets generated repository}

N/A

REASON WHY DATA ARE NOT PUBLIC

N/A

Third party name

N/A

ONLY TO BE INCLUDED IN EMAIL FOR NON-RESEARCH ARTICLES E.G. STUDY PROTOCOLS OR LITERATURE REVIEWS

Not applicable.

Share your raw data

N/A

\section{References}

1. Oyeyinka, S.A., Singh, S. and Amonsou, E. O. 2017. Physicochemical properties of starches extracted from bambara groundnut landraces. Starch/Stärke. 69:1600089.

2. Marinangeli, C. P. and Jones, P. J. 2011. Whole and fractionated yellow pea flours reduce fasting insulin and insulin resistance in hypercholesterolaemic and overweight human subjects $<$ bi $>$. British Journal of Nutrition</bi $>105: 110$ 117.

3. Fuentes-Zaragoza, E., Riquelme-Navarrete, M., SÁnchez-Zapata, J. E., Pérez, A. and Ivarez, J. A. 2010. Resistant starch as functional ingredient: a review. Food Research International 43:931-942.

4. Zhang, B., Deng, Z., Ramdath, D. D., Tang, Y., Chen, P. X., Liu, R. and Tsao. R. 2015. Phenolic profiles of 20 Canadian lentil cultivars and their contribution to antioxidant activity and inhibitory effects on aglucosidase and pancreatic lipase. Food Chemistry 172:862-872.

5. Singh, B., Singh, J. P., Kaur, A. and Singh, N. 2016. Bioactive compounds in banana and their associated health benefits-a review. Food Chemistry 206:1-11.

6. Federica, G., Giovanni, C. Massimo, R. Sauro, V. and Gianni, S. 2017. Determination of fourteen polyphenols in pulses by high performance liquid chromatography-diode array detection (HPLC-DAD) and correlation study with antioxidant activity and color. Food Chemistry 221:689-697.

7. Amarowicz, R., Isabell, E., Teresa, H., Montserrat, D., Agnieszka, T., Agnieszka, K. and Ronald. B. P. 2009. Antioxidant Activity of a Red Lentil Extract and Its Fractions. International Journal of Molecular Sciences 10:5513-5527.

8. Balasundram, N., Sundram, K. and Samman. S. 2006. Phenolic compounds in plants and agri-industrial by-products: antioxidant activity, occurrence, and potential uses. Food Chemistry 99:191-203. 
9. Paucar-Menacho, L., Berhow, M. Mandarino, J. de Mejia, E. and Chang. Y. 2010. Optimization of germination time and temperature on the concentration of bioactive compounds in Brazilian soybean cultivar BRS 133 using response surface methodology. Food Chemistry 119(2):636-642.

10. Xu J. B. and Chang, S. K. C. 2007. A comparative study on phenolic profiles and antioxidant activities of legumes as affected by extraction solvents. Journal of Food Sciences 72(2):S159-S1.

11. Huang, X., Cai, W. and Xu. B. 2014. Kinetic changes of nutrients and antioxidant capacities of germinated soybean (Glycine max L.) and mung bean (Vigna radiata L.) with germination time. Food Chemistry 143:268-76.

12. Zhou, S. Y. and Zhang, Q. 2012. The influence of difference temperature on the growth of soybean sprouts. Gansu Science and Technology 28:142-143.

13. Chávez-Mendoza, C., Karla, I., Hernández, F. and Esteban, S. 2019. Antioxidant capacity and phytonutrient content in the seed coat and cotyledon of common beans (Phaseolus vulgaris L.) from various regions in Mexico. Antioxidants 8:5.

14. Aguilera, Y., Herrera, T., Liébana, R., Rebollo-Hernanz, M., Sanchez-Puelles, C. and Martín-Cabrejas. M. A. 2015. Impact of melatonin enrichment during germination of legumes on bioactive compounds and antioxidant activity. Journal of Agriculture Food and Chemistry 63:7967-7974.

15. Duenas, M., Martinez-villaluenga, C., Lemon, R. I., Penas, E. and Frias, J. 2015. Effect of germination and elicitation on phenolic composition and bioactivity of kidney beans. Food Research International 70:55-63.

16. Aguilera, Y., Herrera, T., Liébana, R., Rebollo-Hernanz, M., Sanchez-Puelles, C., Benítez, V. and Martín-Cabrejas, M. A. 2014. Effect of illumination on the content of melatonin, phenolic compounds, and antioxidant activity during germination of lentils (Lens culinaris L.) and kidney beans (Phaseolus vulgaris L.). Journal of Agriculture Food and Chemistry 62:10736-10743.

17. Kumar, G. and Baojun, X. 2017 Polyphenol-Rich Dried Common Beans (Phaseolus vulgaris L.) and Their Health Benefits. International Journal of Molecular Sciences 18: 23-31.

18. Amarowicz, R., Estrella, I., Hernández, T. and Troszyńska, A. 2008. Antioxidant activity of extract of adzuki bean and its fractions. Journal of Food Lipids 15:119-136.

19. Rybiński, W., Magdalena, K., Katarzyna, S. and Ryszard, A. 2019. Antioxidant Activity of Faba Bean Extracts. Intech Open. p 1-9.

20. Amarowicz. R. and Troszyńska. A. 2003. Antioxidant activity of extract of pea and its fractions of low molecular phenolics and tannins. Polish Journal of Food and Nutrition Sciences 53:10-15.

21. Amarowicz, R. and Shahidi. F. 2017. Antioxidant activity of broad bean seed extract and its phenolic composition. Journal of Functional Foods 38:656-662.

22. Karamać, M., Orak, H., Amarowicz, H., Orak, R. A. and Piekoszewski, W. 2018. Phenolic contents and antioxidant capacities of wild and cultivated white lupin (Lupinus albus L.) seeds. Food Chemistry 258:1-7.

23. Orak, H. H., Karamać, M., Orak, A. and Amarowicz, R. 2016. Antioxidant potential and phenolic compounds of some widely consumed Turkish white bean (Phaseolus vulgaris L.) varieties. Polish Journal of Food and Nutrition Sciences 66:253-260.

24. Rybiński, W., Karamać, M., Sulewska, K., Börner, A. and Amarowicz, R. 2018. Antioxidant potential of grass pea seeds from European countries. Foods 7(9):142.

25. Saleh, H. M., Amal, A. H., Esam, H. M., Hany, A. F. and Abo El-Fath, A. E. 2019. Melatonin, phenolics content and antioxidant activity of germinated selected legumes and their fractions. Journal of the Saudi Society of Agricultural Sciences 18:294-301.

26. Salem, A. A., El-Bostany, A. N., Al-Askalany, S. A. and Thabet, H. A. 2014. Effect of domestic processing methods of some legumes on phytochemicals content and in vitro bioavailability of some minerals $<$ bi $>.</ b i>$ Journal of American Sciences 10:276-288. 
27. Nair, S. S., Nithyakala, C. M., Noronha, I., Sultana, G. N. and Somashekharaiah, B. V. 2012. Isolation and determination of nutritional and antinutritional compounds from the seeds of selected plant species. International Journal of Pharmaceutical Research 4(7):3529-3534.

28. Awada, S. H., Hady, H., Hassan, A. B., Isamali, M., and Babiker, E. E. 2005. Antinutritional factors content and availability of Protein, Starch and Mineral of Maize (Zea mays linnaus) and Lentil (Lens culinaris) as influenced by domestic processing. International Journal of Food Technology 3(4):523-528.

29. Zhao. Y., Shuang-kui, D., Hanxin, W. and Meng. C. 2014. In vitro antioxidant activity of extracts from common legumes. Food Chemistry 152:462-466.

30. Amarowicz, R., Estrella, I., Hernández, T., Robredo, S., Troszyńska, A., Kosińska, A. and Pegg, R. B. 2010. Free-radical scavenging capacity, antioxidant activity, and phenolic composition of green lentil (Lens culinaris). Food Chemistry 121:705-711.

31. Gomes, M. P. and Garcia. Q. S. 2013. Reactive oxygen species and seed germination. Biologia 68(3):351-357.

32. Rusydi, M. and Azrina, A. 2012. Effect of germination on total phenolic contents in soybean and peanut. International Food Research Journal 19(2):673-677.

33. Khang, D. T., Tran, N. D., Abdelnaser, A. E., and Tran. D. X. 2016. Phenolic Profiles and Antioxidant Activity of Germinated Legumes. Foods 5(27):1-10.

34. Zhaohui, X., Cen, W., Lijuan, Z., Wancong, Y., Huiru, C., Xiaohong, K. and Fengjuan, Z. 2016. Bioactive compounds and antioxidant activity of Mung Bean (Vigna radiata L.), Soybean (Glycine max L.) and Black Bean (Phaseolus vulgaris L.) during the germination process, food technology and economy, engineering and physical properties. Czech Journal of Food Sciences 34(1):68-78.

35. Boudjou, S., Oomah, B. D., Zaid, F. and Hosseinian, F. 2013. Phenolics content and antioxidant and anti-inflammatory activities of legume fractions. Food Chemistry 138:1543-1550.

36. Dueñas, M., Hernández, T., Estrella, I. and Fernández, D. 2009. Germination as a process to increase the polyphenol content and antioxidant activity of lupin seeds (Lupinus angustifolius L.). Food chemistry 117(4): 599-607.

37. Emily, M. T., Padhi, R. L., Marta, H., Rong, T. D. and Dan. R. 2017. Total polyphenol content, carotenoid, tocopherol and fatty acid composition of commonly consumed Canadian pulses and their contribution to antioxidant activity. Journal of Functional Foods 38:602-611.

38. Fernandez-Orozco, R., Frias, J., Zielinski, H., Piskula, M.K., Kozlowska, H. and Vidal-Valverde, C. 2008. Kinetic study of the antioxidant compounds and antioxidant capacity during germination of Vigna radiata cv. emmerald, Glycine max cv. jutro and Glycine max cv. merit. Food Chemistry 111(3): 622-630.

39. Dalaram, S. I., Alena, V. and Maria, T. 2013. Bioactive compounds in commonly utilized legumes cultivars from Iraq. Journal of Microbiology, Biotechnology and Food Sciences 2(1):2032-2042.

40. Gubanenko, G. A., Zykova, I. D., Naimushina, L. V., Rechkina, E. A. and Mayurnikova, L. A. 2019. Antioxidant activity evaluation of aqueous extracts of chickpea and lentil seedlings. Environmental Earth Sciences 315:052-015.

41. Fouad, A.A. and Rehab, F.M. 2015. Effect of germination time on proximate analysis, bioactive compounds and antioxidant activity of lentil (Lens culinaris Medik.) sprouts. Acta Scientiarum Polonorum Technologia Alimentaria 14(3): 233-246.

42. Guajardo-Flores D, Serna-Saldívar SO, Gutiérrez-Uribe JA. 2003. Evaluation of the antioxidant and antiproliferative activities of extracted saponins and flavonols from germinated black beans (Phaseolus vulgaris L.). Food chemistry. 141(2):1497-503.

43. Han, H. and Baik, B. K. 2008. Antioxidant activity and phenolic content of lentils (Lens culinaris), chickpeas (Cicer arietinum L.), peas (Pisum sativum L.) and soybeans (Glycine max), and their quantitative changes during processing. International Journal of Food Sciences and Technology 43:1971-1978. 
44. Francisco, M.L.D.L. and Resurreccion, A.V.A. 2008. Functional components in peanuts. Critical Review in Food Sciences and Nutrition 48:715-746.

45. Yao, Y., Cheng, X. Wang, L. Wang, S. and Ren. G. 2011. Biological potential of sixteen legumes in China. Journal of Food Sciences 75(1):C9-C13.

46. Lopez-amoros, M., Hernandez, T. and Estrella, I. 2006. Effect of germination on legume phenolic compounds and their antioxidant activity. American Journal of Clinical Nutrition 70(3):451-458.

47. Wang, Y. K., Zhang, X. Chen, G. L. Yu, J. L., Yang Q. and Gao, Y. Q. 2016. Antioxidant property and their free, soluble conjugate and insoluble-bound phenolic contents in selected beans. Journal of Functional Food 24:359-372.

48. Mastura, H.Y., Hasnah H. and Dang. T. N. 2017 Total phenolic content and antioxidant capacity of beans: organic vs inorganic. International Food Research Journal 24(2):510-517.

\section{Figures}

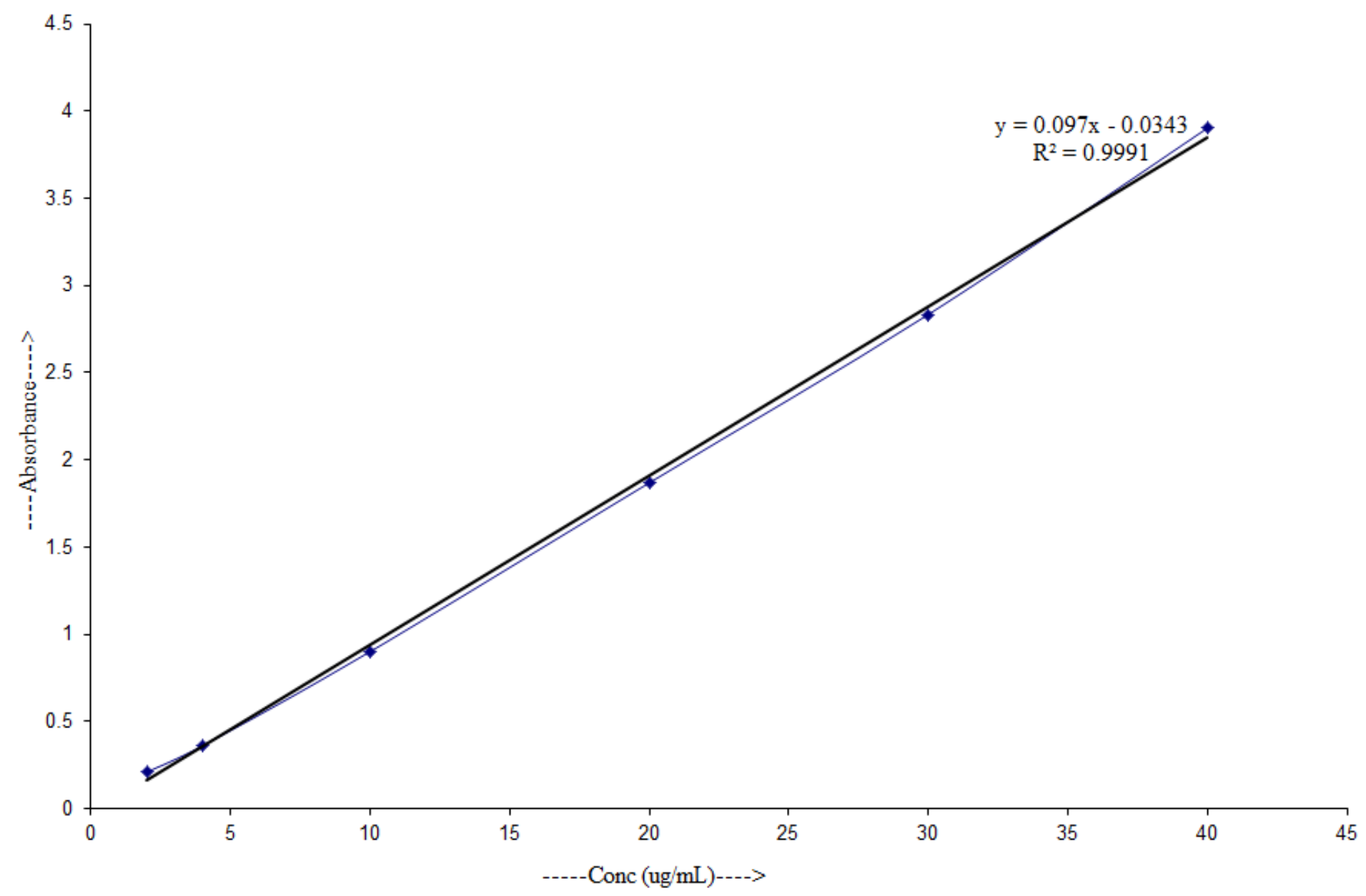

\section{Figure 1}

Calibration curve for gallic acid 


\section{No. of days}

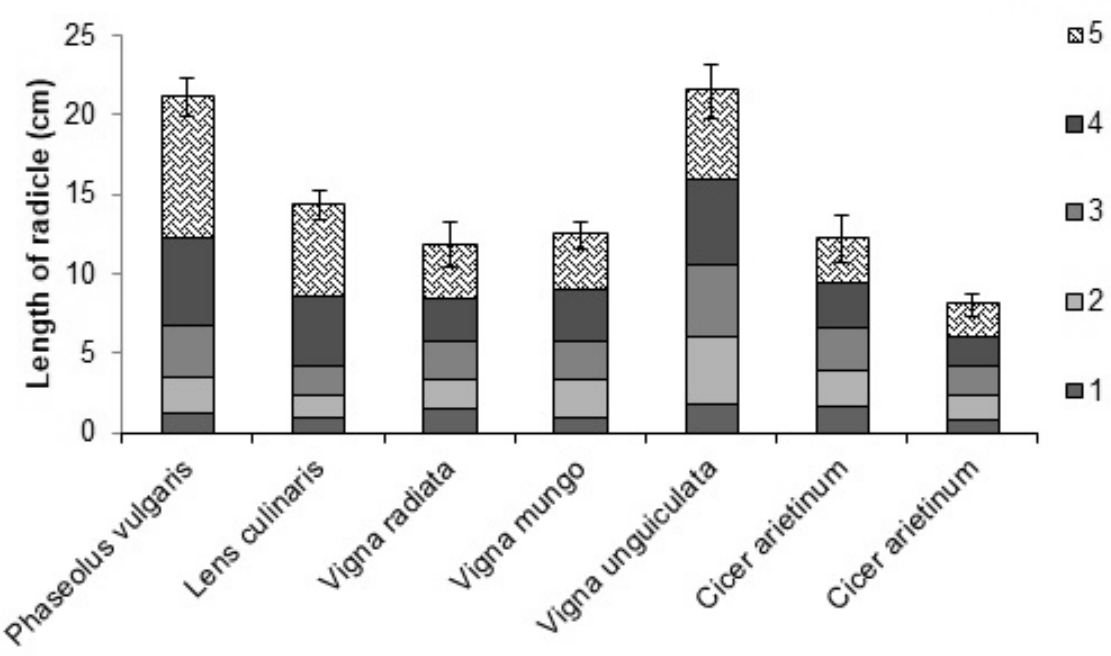

Figure 2

Kinetic changes of radicle length $(\mathrm{cm})$ of beans/lentils with germination time.

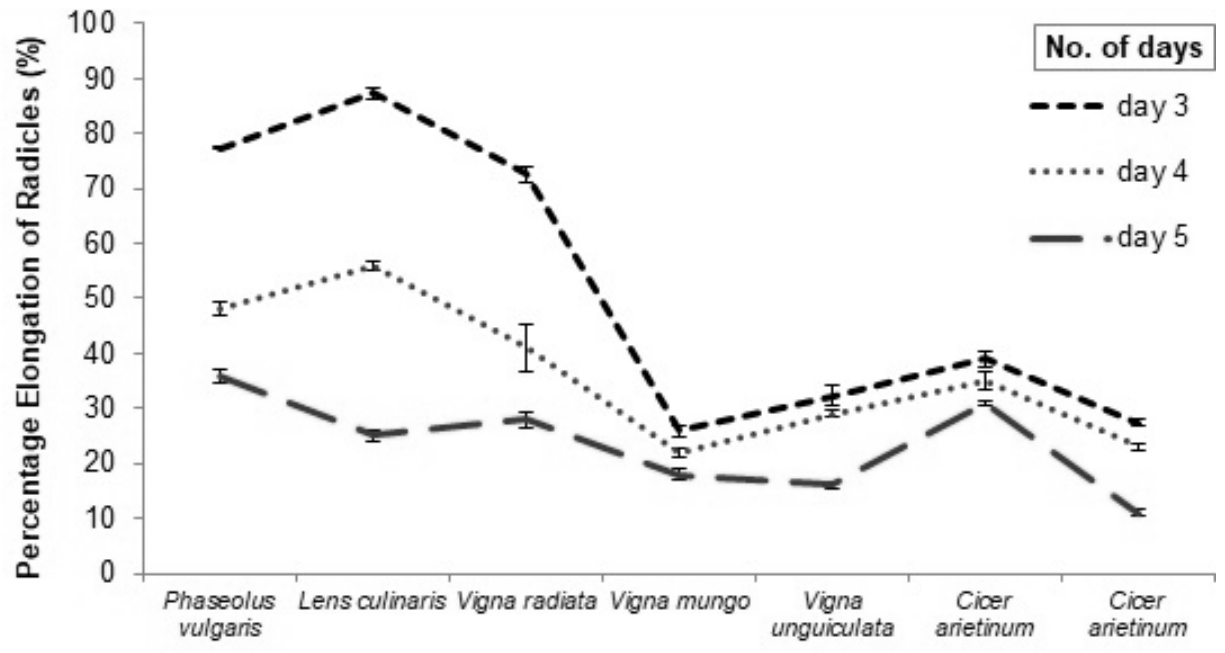

Figure 3

Percentage elongation of radicles (beans/lentils) germination with time. 